\title{
THE USE OF TE REO MĀORI IN ECONOMIC ACTIVITIES IN THE 19TH CENTURY
}

\section{Gianna Leoni*}

\begin{abstract}
Although commerce is often considered to be a primarily Western activity, Māori were, and are, just as engaged in it as anyone else and are internationally recognised today for their business entrepreneurship. Trade and exchange was a common feature in the early history of Māori, both before and after Pākehā contact, as it was one of the main reasons for interaction. The language used in these interactions offers an insight into Māori commercial and economic adaptability and provides a template for how te reo Māori can further develop to support a Kaupapa Māori way of conducting business. This article considers the significance of the Māori language of economics by giving a brief insight into the use of te reo Māori in 19th-century economic activity.
\end{abstract}

\section{Keywords}

Māori language, Māori economy, history, sociolinguistics

\section{Introduction}

Oxford Dictionaries defines language as "the method of human communication, either spoken or written, consisting of the use of words in a structured and conventional way" ("Language”, n.d.). Interactions through trade are not a new phenomenon; they have been present in communities for millennia (Hirst \& Thompson, 2002). The language of economics provides the economic community with the lexicon required to conduct a range of activities. This includes 
customers, investors, bankers and, quite often, the general public, as our lives become more obsessed with money and business.

Māori economics is a fast-growing sector (Nana, Khan \& Schulze, 2015) and the ability to communicate ideas, information and aspirations coherently is imperative. This article stems from the first phase of a Ngā Pae o te Māramatanga Postdoctoral Research Fellowship in the Whai Rawa theme that supports lexicon development by investigating how Māori historically and currently discuss economic activities in te reo Māori. The overall aim of the project, called Te Ōhanga o te Pīpīwharauroa-Expressing Our Economic Aspirations, is to enhance the contemporary Māori language of economic development so that it reflects a Kaupapa Māori way of doing business, with the intention of reintroducing and developing appropriate language in Māori that expresses economic activity.

A common question that has arisen over the past 30 years is what makes a Māori business Māori? And while there are many arguments and discussions that provide a range of answers (see Durie, 2003; Harmsworth, 2005; Te Puni Kōkiri, 2006), this article will instead focus on the characteristics of a business that is Māoricentred, that is, "a business that deliberately revolves around Māori people, Māori assets, and Māori priorities" (Durie, 2003, p. 430). For many Māori-centred businesses there is an extra level of accountability that involves how they are servicing their stakeholders and, in particular, iwi, hapū and whānau. It is imperative for Māori-centred businesses to bear in mind how they communicate with these groups (Durie, 2003). Although language is not a prerequisite for Māori-centred businesses, often it is necessary to connect using a Māori worldview and values in order to convey messages in a way that makes sense to these stakeholders. This is especially important considering that English is now considered "the global language of business" (Neeley, 2012) and therefore predominates in this domain.
Articulating ideas in a way that embraces Te Ao Māori is important because "it can only be by way of the Māori language that the absolute richness of the culture, the people and their histories, concepts and knowledge can be experienced" (Rewi, 2012, p. 88). Margaret Mutu (2009) supports this notion when she discusses the importance of oral traditions being recounted in Māori rather than English, and how the failure to do so "will always add a foreign cultural layer that detracts from the underlying meaning and cause the original to lose essential nuances" (p. 41). It is through te reo Māori that cultural values and ideas can be explained in a way that makes sense to a Māori worldview.

For Māori-centred businesses to align with Māori values and economics, they need language that allows them to do so, that makes sense to a Māori worldview, and that enables them to uphold their responsibilities to their stakeholders. Although there is economic terminology available in te reo Māori, there is always room for improvement. Te Ōhanga o te Pīpīwharauroa seeks to strengthen lexicon development in this area.

This article discusses some of the findings from phase one of Te Ōhanga o te Pīpīwharauroa. The purpose of this phase was to identify Māori economic language used in the 19th century: a time when te reo Māori was the language of wider communication and Māori values were prominent. Despite there being an extensive range of literature that examines the Māori language in the 19th century (Haami, 2004, 2012; Karetu, 2002; Moorfield \& Paterson, 2002; O'Regan, 2012; Rewi, 2012) and of the Māori economy in this time period (Firth, 2012; King, 2003; Petrie, 2002, 2006; Salmond, 1997; Te Puni Kōkiri, 2007), there is little that connects them both in detail. This is interesting to note as trade would have been one of the main reasons for interaction to occur during this time period, yet specific, sociolinguistic examination of Māori spoken or written words used in economic activity is rare. 
This article endeavours to fill the gap in current research on 19th-century Māori language and economics whilst demonstrating the suitability of te reo Māori used in 19th-century economic activities for modern-day language development in this context. It begins with an explanation of the methods used throughout phase one of Te Ōhanga o te Pīpīwharauroa. It then provides a brief introduction to the Māori economy and the broader use of te reo Māori in the 19th century. Finally, it uses two texts to demonstrate examples of Māori language use in economic activity in this time period: Easy Lessons on Money Matters for the Use of Young People (Whately, 1851) and a passage in Te Karere Maori-Maori Messenger from 1856.

\section{Methods}

Phase one of Te Ōhanga o te Pīpīwharauroa included a selective survey of 19 th-century manuscripts, newspapers and advertisements written in te reo Māori that included discourse about economic activity. This time period was chosen for a number of reasons: (a) trade, notably horticulture, farming, whaling and flour mills, was thriving and Māori were successful in these endeavours at this time; (b) te reo Māori was the language of wider communication of Māori (and non-Māori) throughout Aotearoa up until the late 19th century; and (c) te reo Māori became a written language during this century and, as a result, there are many documents available for examination that have a plethora of examples of language used in economic activity expressed in a Māori way. Moreover, the entire 19th century was included as it provided examples of different contexts of language use that linked to economic activity (e.g., in the early decades texts included discussion on trade associated with whaling, and as time passed the nature of discourse changed to focus on money and how to use it). With a large time period, only one researcher, and a need for a range of examples, it was necessary for the survey to be selective in the literature that was included. There is scope for more literature to be explored, and this phase highlighted the potential for a more comprehensive examination of this literature.

The survey explored a collection of databases to locate texts. The New Zealand Electronic Text Collection, Hocken Library, Alexander Turnbull Library and Papers Past were the main databases utilised. A range of keywords were used to identify a text's relevance to economic activity, but of particular interest were texts that included discussion about trade, money, business, finance, insurance, banking, industry, licensing, agriculture and real estate. This also included the Māori equivalents of the words currently available in dictionaries. Over 200 texts were surveyed, spanning small advertisements to complete books.

Through a close reading of texts, it became evident that there were many similarities in the types of language and words that were used and that these could contribute to the modernday Māori economic lexicon. The long-term objective of this research is to create a resource that will assist in modern-day Māori economic language use. Due to space restrictions, this article discusses only a small sample of texts and describes how they might be reinterpreted and applied to current language use.

A key text of this selective survey was Books in Māori 1815-1900 (Parkinson \& Griffith, 2004), an annotated bibliography compiled by Alexander Turnbull Library researchers that lists "almost every document of printed Māori to $1900 "$ (Hohepa, 2004, p. 7). The entries found in this bibliography include books, pamphlets, single sheet printed items, newspapers, magazines and official publications. In this research, Books in Māori 1815-1900 was used as a starting point to accessing larger texts with more detail.

One fundamental issue that Parkinson and Griffith (2004) identified in the texts was "the evolving nature of the written language. For example, the spelling of words varied, and the 
names of individuals might be presented in different forms" (p. 11). This was due to the lack of conformed orthography in the 19th century. Although every attempt was made to check for any words or names written in different forms, some texts may have been excluded from the searches.

For the purposes of this article, if texts have words printed in a way that is different to contemporary te reo Māori orthography, the standard spelling follows in square brackets (e.g., "ekore [e kore]"). Where quotations have been taken from a source that does not use macrons, this has been replicated as the original source has presented it to ensure the mana of that text stays intact.

\section{The 19th-century Mãori economy, pre-contact}

Research by the Global Entrepreneurship Monitor in 2001 "found Māori to be the most entrepreneurial people in the world" (Petrie, 2002, p. 1). This is evident when one looks at the history of the Māori economy and how it has developed from pre-Pākehā contact to today.

The first types of economic activity in Aotearoa occurred prior to the arrival of Pākehā and served the purpose of communal need rather than commercial trade (Firth, 2012). Hapū were the main political and economic unit for all functional purposes (Ballara, 1998) and members were therefore responsible for the survival of other members. The economy of a hapū or whānau differed depending on the location as it was influenced by the climate, access to local resources and exposure to other hapū. Coastal communities that had access to seafood and marine resources exchanged products with inland communities for berries, birds and rats. Minerals such as flint and pounamu that could be used to make tools, weapons or jewellery were also important trade items (see Petrie, 2006, for more specific discussion on pre-Pākehā trading). Petrie (2006) argues that the exchanging of goods that occurred prior to Pākehā arrival and in the early contact period is often pigeonholed as merely a "gift exchange" by some contemporary academics. The amount of negotiation that took place is frequently downplayed and demonstrates the type of trade and business that took place before Pākehā arrival. In the South Island, for example, trade depots were set up for porters to travel back and forth with their carriage loads of goods (Stack, as cited in in Petrie, 2006).

When Pākehā arrived, they relied on Māori for food and resources to survive, which initiated another degree of economic activity. In return, Māori welcomed trade with Pākehā and the new tools and resources they brought with them. Firearms, cloth, iron and potatoes provided an opportunity for development for Māori that proved to be extremely alluring for chiefs.

\begin{abstract}
Since the ability to ensure optimum food supplies and economic benefits for the community were so essential to the political and economic power of the chief, it should not be surprising that leaders took particular interest in the new crops and technologies they were able to access as a consequence of European contact. (Petrie, 2006, p. 12)
\end{abstract}

The arrival of more Pākehā settlers also saw a surge in land transactions. The need to regulate activities became more apparent, and William Hobson was sent to Aotearoa in 1840 to "take the constitutional steps necessary to establish a British colony" and told to "negotiate a voluntary transfer of sovereignty from Māori to the British Crown" (King, 2003, p. 156). His arrival was soon followed by the signing of the Treaty of Waitangi.

The linguistic and cultural implications of the Treaty of Waitangi have been discussed in great detail by many scholars (Hayward, 2018; Orange, 2001; Ross, 1972; Waitangi Tribunal, 2014; Ward, 1999) and will not be addressed in this article. Instead, it is important to note 
that, in terms of economic activity, Māori took advantage of the growing trading opportunities. Many of these emerged because of the growing number of settlers, the need to grow wheat as a staple of the Pākehā diet, the development of flour milling and increased coastal shipping (Te Puni Kōkiri, 2007). According to Petrie (2006), the 1840s and 1850s were the "golden age" of Māori enterprise. Māori embraced the shift from a barter economy that existed for survival to participating in a cash economy. Māori showed a sound understanding of what was required in order to succeed in an expanding domestic market. Hapū cooperated with one another to acquire flour mills and trading ships, which allowed for the expansion of general food production (Te Puni Kōkiri, 2007).

Māori were also willing participants in international trade. This involved travelling overseas, where they learnt about foreign markets, goods and economic systems before returning home to their whānau and hapū. When returning home they brought with them presents and new innovations that would allow the growth and development of their communities, such as wheat cultivation and dairy farming (Petrie, 2002).

By the late 1850s, however, the flour milling and shipping industries began to decline and the influence of Christianity and literacy grew. The number of Pākehā equalled the number of Māori by the mid to late 1850s (Pool, 1991). The creation of a Pākehā parliament and the ever-increasing demand for land by settlers saw Māori gradually fall behind in the economic race, and they eventually lost their autonomy as a result. This continued for the rest of the 19th century, which made it difficult for Māori to fully engage in the economy thereafter.

\section{Māori language use in the 19th century}

Before contact with Pākehā, the use of language in Aotearoa was "operating at the most fundamental level” (Rewi, 2012, p. 74). There was no formal literacy, so knowledge, stories, histories and tikanga were stored through art forms such as whakairo, tukutuku and tā moko, as well as kōrero tuku iho, waiata and karakia (Haami, 2004). According to James Belich (1996),

Māori preserved myth, religion, custom, geography, lore and law, explanations of nature, guidance about the future, and many other types of knowledge in the same medium. These strands are not easily separated, and they were not intended to be. They were integrated so that each assisted the remembering of the other; a tapestry that could be wholly unravelled or revealed by continuous tugging on one of its threads. (p. 22)

When the eastern Polynesian ancestors of Māori arrived in Aotearoa, they would have encountered a new environment that had both similarities and differences to the place they had travelled from. This would have facilitated a transfer of linguistic terms that were needed to describe their new home. New terms would have been devised "by way of trial, comparative sounds, biological similarity or improvised utterance" (Rewi, 2012, p. 80).

The first consistent contact with Pākehā travellers occurred late in the 18th century (Salmond, 1997). These initial relations impacted on te reo Māori immediately as both sides attempted to communicate. The process of creating transliterations was used to address the increasing influence of English (Moorfield \& Paterson, 2002; O’Regan, 2012). As a result, new Māori words were created "without any direct cultural meaning or customary history: words that were Māori in sound, but Pākehā in meaning" (Rewi, 2012, p. 87). For example, the word "wìra" was created for "wheel" and "wheketere" for "factory". The creation of loanwords allowed for the modernisation of the language to describe the new technology Māori encountered, as well as enabling them to 
undertake transactional interactions and other exchanges with Pākehā in te reo Māori.

Despite this process appearing to indicate the language was developing, I believe the creation of loanwords had a somewhat negative impact. Some transliterations even replaced traditional words. "Hìtori" for "history", for example, began to be used instead of "kupu tuku iho" (lit. "words handed down"). This was also true for place names, where a Māori name for an area would be replaced with a transliteration for the English name that had been given to a town. For example, Pāmutana is a transliteration for Palmerston North, but Te Papaioea is the traditional name for the area. This process of transliterating stuck and changed the way te reo Māori progressed (it is important to note that hapū would have been impacted differently as a result of unique experiences of colonisation). The influence of missionaries and settlers also caused a semantic change in the meaning of Māori words. For example, before Pākehā contact, the term "atua" meant "ghost" or "malevolent spirit", but as a result of Christian influence it began to be used to describe a "singular missionary-defined omnipotent god" (Haami, 2012, p. 171), which is evident in many karakia today.

In the early 1800 s, missionaries learnt Māori in order to teach English and Christianity to Māori. Literacy was crucial in the attempts by missionaries to introduce Māori to Christianity and "a better way of life". The written word and print literacy were completely unfamiliar concepts to Māori, "where letters, lines and symbols were delineated to express not only linguistic utterances but cultural perceptions and knowledge to be read and reconstructed" (Haami, 2012, p. 165). This new method of expressing te reo Māori was accepted very quickly by Māori (Jones \& Jenkins, 2011). Many of the earliest examples of written Māori are religious in nature, such as translations of Bible texts. But Māori soon understood the benefits they would receive and wanted the opportunity to increase their economic interactions with Pākehā. Other forms of written Māori also emerged, such as recording histories, memories and knowledge, and writing letters (Haami, 2012).

However, it was not just Māori who relished the opportunities print media offered. The government soon realised the value of producing texts and newspapers in te reo Māori and how they could assist in the colonisation project (Curnow, 2002). The first Māorilanguage newspaper, Te Karere o Niu Tireni, appeared in January 1842. One of the first sentences in the first edition discussed the reason for printing the newspaper, which was "kia mohio ai te tangata maori ki nga tikanga me nga ritenga o te Pakeha, kia mohio ai ano hoki te Pakeha ki nga ritenga o te maori" ("Untitled", 1842). This roughly translates as "to enlighten Māori on the practices and customs of the Pākehā, and to enlighten Pākehā on the customs of the Māori". This quote has two interesting features. Firstly, the colonials (Pākehā) asserted their position in the hierarchy by capitalising the "P" in Pākehā and using a small " $\mathrm{m}$ " for Māori (this did change in later editions). Secondly, the first part of the sentence was most certainly the main reason for Pākehā printing these newspapers. Informing Māori of Pākehā customs, religious spiels, and explanations of new legislation, among other things, were the main messages of these early newspapers (Curnow, 2002), rather than simultaneously teaching Pākehā about Māori. Another newspaper, Te Karere Maori-Maori Messenger, was very similar in nature and "had a heavy bias towards matters of commerce and political economy, interspersed with Christian messages, lessons on childcare, appropriate work for women, and general knowledge" (Petrie, 2002, p. 10).

Eventually Māori responded by using newspapers as a tool to "apprise government and Pakeha of Māori opinion, to unify Maori through thought and action, particularly in regard to land, and to educate Maori about their own society and the world" (Curnow, 2002, p. 17). These newspapers gave Māori 
some autonomy and a chance to gain a more equal footing in society. However, as a result of government policies, the Māori economy dwindled in the 1870s; so too did the Mãori language and culture. By the 1900s language transmission between generations of Māori ceased as a result of the implementation of a policy that encouraged the use of English. Without knowing the repercussions of accepting and agreeing to these policies, Māori witnessed their language nearly become extinct.

Patu Hōhepa (2004) states that "the greatest gift England gave Māori was literacy" (p. 6). However, the introduction of literacy and print culture to Aotearoa had both advantages and disadvantages. On the one hand, it permitted the retention of histories and stories, and it allowed Māori to express their opinion publicly. On the other, it "contributed to the loss of Māori orality” (Haami, 2012, p. 190), and secondly, in relation to the lexicon specifically, the language became less flexible and more emphatic (Karetu, 2002).

\section{Examples of Māori language used in 19th-century economic activity}

The English terminology used to describe economic activity during the 19th century is still relevant today, but it would have been very difficult to translate into te reo Māori. Terms such as "price fixing”, "profit margin”, "commercial", "customs tariff", "investment", "loan" and "taxation" would have been completely foreign to pre-Pākehā Māori trade practices, yet the concepts behind them would have been crucial to successful business transactions upon the introduction of money. This section provides examples of words or phrases from two texts found during this examination.

\section{He pukapuka reo Maori tenei ...}

Englishman Richard Whately published Easy Lessons on Money Matters for the Use of
Young People in 1837, and a Māori translation appeared in 1851 as He pukapuka reo Maori tenei, He pukapuka ako inga tikanga o te moni, o te hokohoko, o te aha, o te aha (Whately, 1851). This provides an insight into economic language in te reo Māori from the 19th century that is still relevant today. The book was translated into Māori at the instruction of the colonial government for "the benefit of the Native population of these Islands, through which they may acquire knowledge in its various useful branches" (Whately, 1851, p. 5). Although the majority of the text is written only in te reo, the table of contents is printed in both te reo and English. Not only do the contents pages provide the basis of subject matter; they also offer an insight into how the translation from English into te reo Māori was carried out. Excerpts from the contents are collated in Table 1.

The Māori words that are capitalised correspond to their English counterparts in the left-hand side of the table. The term "ko nga tikanga" refers to the "correct practice" or "procedure" involved in each of the sections. Several of the English economic terms are quite easily described in te reo Māori, such as "money" ("moni”), "exchanges" ("hokohoko"), "wages" ("utu o te mahi"; lit. "the cost of work") and "taxes" ("takiha"; now "tāke").

However, many of the English concepts required a longer explanation because the colonial context of the word used in English was unfamiliar in te reo Māori as a result of varying worldviews. For example, the word "hokohoko" is used is describe two different Māori concepts: exchange and commerce. The addition of "ke ano [kē anō]" ("again”, "another") to the explanation of "commerce" highlights that it is another type of exchange. Oxford Dictionaries defines commerce as "the activity of buying and selling, especially on a large scale" ("Commerce", n.d.), which strongly correlates with words such as "trade" (buying and selling) and "exchange". But it also includes wider actions that are crucial to the success of 
TABLE 1 Bilingual contents excerpts from the Māori translation of Easy Lessons on Money Matters for the Use of Young People (Whately, 1851)

\begin{tabular}{|c|c|}
\hline Contents & Ko Nga Whakaritenga-O Nga Upoko \\
\hline Money & Ko nga tikanga o te Taonga nei o te MONI \\
\hline Exchanges & Ko nga tikanga o te mahi nei, o te $\mathrm{HOKOHOKO}$ \\
\hline Commerce & $\begin{array}{l}\text { Ko nga tikanga i Nga Rawa o tetehi Whenua-e utua nei mo } \\
\text { nga Rawa o tera Whenua ke atu HE HOKOHOKO KE ANO }\end{array}$ \\
\hline Coin & $\begin{array}{l}\text { HE WHAITAKINGA TENEI I NGA TIKANGA O NGA } \\
\text { MONI KATOA }\end{array}$ \\
\hline Of Value & Ko nga tikanga o te kupu nei o TE TAONGA \\
\hline Wages & Ko nga tikanga o te UTU O TE MAHI a te tangata \\
\hline Rich and Poor & $\begin{array}{l}\text { Ko nga tikanga i WHAI TAONGATIA ai tetehi Hunga- } \\
\text { i RAWAKORE ai TETEHI Hunga }\end{array}$ \\
\hline Capital & $\begin{array}{l}\text { Ko nga tikanga enei o te tangata, i a ia nei Nga PUNA O TE } \\
\text { MONI e takoto ana }\end{array}$ \\
\hline Taxes & Ko nga tikanga o Nga Moni e kiia nei HE TAKIHA \\
\hline Letting and Hiring & $\begin{array}{l}\text { Ko nga tikanga o te mea e tuku nei i te ONE ONE, i te } \\
\text { TAONGA RANEI,--kaore hanga o te tuku oti atu-erangi } \\
\text { ano, o te tuku whakahoki ano ki te tangata nona uga } \\
\text { [nga] Rawa }\end{array}$ \\
\hline $\begin{array}{l}\text { Interference with Men's } \\
\text { Dealings with Each Other }\end{array}$ & $\begin{array}{l}\text { Ko nga tikanga o te tangata e poka atu nei ki runga ki nga mea } \\
\text { o tera tangata WHAI TIKANGA AI-WHAI KUPU ai ranei }\end{array}$ \\
\hline
\end{tabular}

Note. Original capitalisation.

an exchange. Today, "tauhokohoko" can be used as a verb (to barter, bargain, trade) or, when used as a noun, can define "commerce", whereas "hokohoko" is used as a verb. On a more informal level, some people will say "whare hokohoko" in reference to secondhand stores.

"Whai taongatia" is used in this text for the term "rich" and "rawakore" is used for "poor". This is interesting because before Pākehā arrived there was no sense of rich or poor with respect to money; wealth was instead measured in terms of resources such as minerals, as discussed previously. So these terms have been coined in relation to terminology that was comprehensible to Māori, such as "taonga", a word that was commonly accepted to represent something precious or "having received or achieved treasures". "Whai taongatia" is used here to describe the action of "pursuing treasures", and in relation to the language of economy, this would mean a person who does so is rich.
The term "rawakore" reflects the notion of not having (kore) any goods, resources or chattels (rawa). "Rawakore" is still used today, but the loanword "pōhara" is heard more frequently in relation to being poor or in poverty.

The term "capital", in economics, is defined as "wealth in the form of money or other assets owned by a person or organization" ("Capital", n.d.). Terms such as "moni tōpū” (combined money) and "haupu rawa" (wealth fund) are used to describe the use of "capital" in the modern-day financial lexicon. The section on capital in Easy Lessons on Money Matters discusses how it is important to employ workers for tasks that will return a profit, such as working in a corn mill, rather than pleasure, like building a summer house. The section states that the wealth received from good business decisions is called "capital". The passage uses "te puna o te wai" to describe its use of "puna moni" and "te puna o te moni" as an interpretation of "capital". "Puna" (spring of water) is often 
combined with other words to describe a source or collection of things, such as "puna mātauranga" (fount of knowledge). Hence, "te puna o te moni" literally translates as a "spring of money". Although "moni" is a transliteration, "te puna o te moni" could be added to definitions of "capital" as an adequate alternative.

\section{"Market Fluctuations—Ngā Ritenga Hoko Hoko"}

A bilingual passage in the Te Karere MaoriMaori Messenger from July 31, 1856, discusses "market fluctuations" and the inability of Māori to understand what this meant ("Market Fluctuations”, 1856). It talks about how Māori had travelled to Australia in search of gold. Requiring sustenance, they found food was often scarce in Australia, and that produce would be purchased from New Zealand at a high price because of the demand. Eventually the Australians caught on and began to produce their own crops and no longer needed to purchase food from New Zealand. As a result, the price of produce in New Zealand dropped. This passage is written bilingually and provides several examples of economic language use.

The passage discusses how markets are "subject to constant change and fluctuation" ("Market Fluctuations", 1856). In the Māori version this is translated as "ekore [e kore] e tuturu, e piki ana, e heke ana nga utu". The term "fluctuation" is defined as "an irregular rising and falling in number or amount" ("Fluctuation", n.d.). The term "ngā piki me ngā heke" is frequently heard when talking about success and failure or "ups and downs", and therefore is a suitable translation for "fluctuation". This is an example where a Māori idiom was used to denote an English economic term, rather than creating a transliteration. The use of this idiom would have allowed for better comprehension among readers, avoiding the need to include further explanation, which would have been necessary if a loanword had been created.
Another sentence in the passage alludes to the notion that Māori believed market fluctuation was because of the unwillingness of Pākehā "to give them a fair value for their produce". The Māori version reads "he kaiponu i nga utu tika mo aua tini kai e kawea mai nei". In Te Ao Māori, "tika" is often associated with things that are "correct" or "true". It has been used here to represent "fair" in the sense that it is "just or appropriate in the circumstances" ("Fair", n.d.). The inclusion of "utu" as a term for "cost" or "value" makes the phrase "utu tika" mean a "fair value" from an economic perspective. The use of "utu tika" is another example of describing a concept in a way that makes sense in Te Ao Māori rather than using "wāriu", which Te Aka (Moorfield, 2005) states is a loanword for "value".

\section{Conclusion}

The purpose of this article has been to demonstrate that 19th-century Māori economic language can support the development of the modern Māori economic lexicon. It has provided new insight into the Māori economy, and general use of te reo Māori, in the 19th century. The article also provided examples of te reo Māori being used in expressing economic activity that were not just transliterations of English economic ideas or expressions. Throughout this phase of the research project it became evident that there is a plethora of examples of Māori ways of thinking being used to describe economic activity.

Some of the terminology that emerges from this selective survey could be reintroduced into te reo Māori to describe and add value to current economic language use. The use of terms and phrases such as "whai taongatia" and "te puna o te wai" illustrate how writers of te reo Māori in the 19th century included language that was reflective of a Māori worldview and the environment as they understood it. Although some texts were written by Pākehā, there are 
examples of language use, such as the two texts analysed in this article, that were written with Te Ao Māori in mind. I argue that this type of language can be reacquired to support lexicon development in the economic space.

This organic coining of language that is reflective of a Māori worldview, in my opinion, is powerful, particularly when English is referred to as the global language of economics. It allows Māori-centred businesses to assert tino rangatiratanga and empowers Māori to better express themselves in this domain, as English does not always provide appropriate terminology for Māori to express the subtlety or clarity of their economic aspirations. It also aids in avoiding issues of miscommunication in economic activity and in ensuring that the language that is used is framed in a Kaupapa Māori way of thinking, which therefore adds more value to the Māori economy.

The findings from phase one of Te Ōhanga o te Pīpiwharauroa and those of subsequent phases will be used to create a resource that will assist in the use of te reo Māori in economic activity in the future. As this phase of the project conducted only a selective survey, there is also scope for a more extensive examination of the literature from this time period to further support the development of a te reo Māori lexicon in the economic space.

\section{Acknowledgement and disclaimer}

Ka tika me mihi atu ki a Ngā Pae o te Māramatanga mō te pūtea hei whakaoti i tēnei rangahau. Waihoki, ki a rātou mā i āta whakamātau i ēnei kaupapa, arā, ko te reo Māori me te ao ōhanga i te rautau 19.

\section{Glossary}

$\begin{array}{ll}\text { Aotearoa } & \text { New Zealand } \\ \text { atua } & \text { ghost, deity, supernatural } \\ & \text { being, god }\end{array}$

hapū

haupū rawa

hìtori

hokohoko

iwi

karakia

kaupapa

Kaupapa Māori

ke ano

kōrero tuku iho

kupu tuku iho

mana

moni

moni tōpū

ōhanga

Pākehā

Pāmutana

pike me ngā heke

pīpīwharauroa

pōhara

pounamu

puna

puna mātauranga

puna moni

puna o te moni

puna o te wai

rawakore

tāke

takiha

tā moko

taonga

tauhokohoko

Te Ao Māori

Te Papaioea

te reo Māori

tika

tikanga kinship group, sub-tribe, clan

capital (finance)

history

to trade, exchange, barter

tribe

prayer, incantation topic, purpose, issue

Māori customary practice

again, another

history, oral tradition

history, oral history

prestige, authority, status

money

capital (finance)

economics, nest

European settlers and migrants

Palmerston North

ups and downs

shining cuckoo

poor, in poverty

greenstone

spring, well

fount of knowledge

capital (finance)

capital (finance)

spring of water

poor

taxes

taxes

Māori traditional tattooing

treasure, something that is precious

to barter, trade; commerce

the Māori world

Palmerston North the Māori language to be correct, true, fair correct procedure, custom 


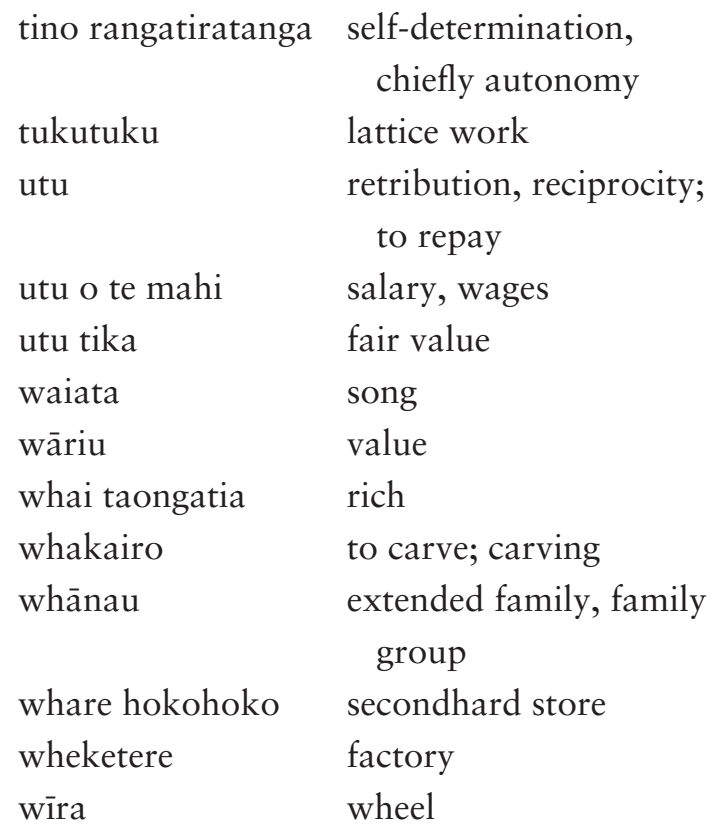

\section{References}

Ballara, A. (1998). Iwi: The dynamics of Māori tribal organisation from c. 1769 to c. 1945 . Wellington, New Zealand: Victoria University Press.

Belich, J. (1996). Making peoples: A history of the New Zealanders from Polynesian settlement to the end of the nineteenth century. Auckland, New Zealand: Penguin.

Capital. (n.d.). In Oxford Dictionaries. Retrieved from https://en.oxforddictionaries.com/definition/ capital

Commerce. (n.d.). In Oxford Dictionaries. Retrieved from https://en.oxforddictionaries.com/ definition/commerce

Curnow, J. (2002). A brief history of Maori-language newspapers. In J. Curnow, N. Hopa \& J. McRae (Eds.), Rere atu, taku manu! Discovering history, language and politics in the Maori language newspapers (pp. 17-41). Auckland, New Zealand: Auckland University Press.

Durie, M. (2003). Ngā kāhui pou: Launching Māori futures. Wellington, New Zealand: Huia.

Fair. (n.d.). In Oxford Dictionaries. Retrieved from https://en.oxforddictionaries.com/definition/fair

Firth, R. (2012). Primitive economics of the New Zealand Maori. London, UK: Routledge.

Fluctuation. (n.d.). In Oxford Dictionaries. Retrieved from https://en.oxforddictionaries.com/ definition/fluctuation

Haami, B. (2004). Pūtea whakairo: Māori and the written word. Wellington, Aotearoa New Zealand: Huia.

Haami, B. (2012). Tā Te Ao Māori-Writing the Māori world. In D. Keenan (Ed.), Huia histories of Māori: Ngā tāhubu kōrero (pp. 163-195). Wellington, New Zealand: Huia.

Harmsworth, G. (2005). Report on the incorporation of traditional values/tikanga into contemporary Māori business organisations and process. Palmerston North, New Zealand: Landcare Research and Mana Taiao Limited.

Hayward, J. (2018). He Whakaputanga me te Tiriti: The Declaration and the Treaty. In M. Reilly, S. Duncan, G. Leoni, L. Paterson, L. Carter, M. Rātima \& P. Rewi (Eds.), Te kōparapara: An introduction to the Māori world (pp. 180-193). Auckland, New Zealand: Auckland University Press.

Hirst, P., \& Thompson, G. (2002). The limits to economic globalization. In D. Held \& A. McGrew (Eds.), The global transformations reader: An 
introduction to the globalization debate (2nd ed., pp. 335-348). Cambridge, England: Polity Press.

Hohepa, P. (2004). Preface. In P. Parkinson \& P. Griffith (Eds.), Books in Māori 1815-1900Ngā tānga reo Māori (pp. 6-8). Auckland, New Zealand: Reed.

Jones, A., \& Jenkins, K. (2011). He kōrero-Words between us: First Māori-Pākehā conversations on paper. Wellington, New Zealand: Huia.

Karetu, T. (2002). Maori print culture: The newspapers. In J. Curnow, N. Hopa \& J. McRae (Eds.), Rere atu, taku manu! Discovering history, language and politics in the Maori language newspapers (pp. 1-16). Auckland, New Zealand: Auckland University Press.

King, M. (2003). The Penguin history of New Zealand. Auckland, New Zealand: Penguin.

Language. (n.d.). In Oxford Dictionaries. Retrieved from https://en.oxforddictionaries.com/definition/ language

Market fluctuations- $\mathrm{Ngā}$ ritenga hoko hoko. (1856, July 31). Te Karere Maori-Maori Messenger. Retrieved from https://papers past.natlib.govt.nz/newspapers/maori-messen ger-te-karere-maori/1856/07/31/4

Moorfield, J. C. (2005). Te aka: Māori-English, English-Māori dictionary and index. Auckland, New Zealand: Pearson Education New Zealand.

Moorfield, J. C., \& Paterson, L. (2002). Loanwords used in Maori-language newspapers. In J. Curnow, N. Hopa \& J. McRae (Eds.), Rere atu, taku manu!: Discovering history, language \& politics in the Māori-language newspapers (pp.60-77). Auckland, New Zealand: Auckland University Press.

Mutu, M. (2009). The role of history and oral traditions in recovering Fagin's ill-gotten gains: Settling Ngāti Kahu's Treaty of Waitangi claims against the crown. Te Poubere Kōrero, 3, 23-44.

Nana, G., Khan, M., \& Schulze., H. (2015). Te ohanga Māori 2013: Māori economy report 2013. Retrieved from http://www.tpk.govt.nz/ en/a-matoumohiotanga/search?q=asset+base

Neeley, T. (2012). Global business speaks English. Retrieved from https://hbr.org/2012/05/ global-business-speaks-english

Orange, C. (2001). Illustrated history of the Treaty of Waitangi. Wellington, New Zealand: Bridget Williams Books.

O'Regan, H. (2012). The fate of the customary language: Te reo Māori 1900 to the present. In D. Keenan (Ed.), Huia histories of Māori: Ngā tāhuhu kōrero (pp. 297-323), Wellington, New Zealand: Huia.

Parkinson, P., \& Griffith, P. (Eds.). (2004). Books in Māori 1815-1900-Ngā tānga reo Māori. Auckland, New Zealand: Reed.

Petrie, H. (2002). Colonisation and the involution of the Maori economy. Paper presented at XIII World Congress of Economic History, Buenos Aires. Retrieved from http://news.tangatawhenua.com/ wp-content/uploads/2010/10/24Petrie75.pdf

Petrie, H. (2006). Chiefs of industry: Māori tribal enterprise in early colonial New Zealand. Auckland, New Zealand: Auckland University Press.

Pool, I. (1991). Te iwi Maori; A New Zealand population, past, present and projected. Auckland, New Zealand: Auckland University Press.

Rewi, P. (2012). "An active and functional language": Te reo in the early contact period. In D. Keenan (Ed.), Huia histories of Māori: Ngā tāhubu kōrero (pp. 73-89). Wellington, New Zealand: Huia.

Ross, R. M. (1972). Te Tiriti o Waitangi: Texts and translations. New Zealand Journal of History, 6(2), 129-157.

Salmond, A. (1997). Between worlds: Early exchanges between Maori and Europeans. Auckland, New Zealand: Viking.

Te Puni Kōkiri. (2006). Hei whakamārama ingā āhuatanga o te tūrua pō-Investigating key Māori business characteristics for future measures: Thinking paper. Wellington, New Zealand: Te Puni Kōkiri and Federation of Māori Authorities.

TePuniKōkiri.(2007).Historicalinfluences-Māoriand the economy. Retrieved from https://www.tpk. govt.nz/documents/download/102/tpk-histoic influence-2007-eng.pdf

Untitled. (1842, January 1). Te Karere o Niu Tireni. Retrieved from https://paperspast.natlib.govt.nz/ newspapers/MMTKM18420101.2.2

Waitangi Tribunal. (2014). He whakaputanga me Te Tiriti: The Declaration and the Treaty, WAI 1040. Lower Hutt, New Zealand: Legislation Direct.

Ward, A. (1999). An unsettled history: Treaty claims in New Zealand today. Wellington, New Zealand: Bridget Williams Books.

Whately, R. (1851). He pukapuka reo maori tenei, he pukapuka ako inga tikanga o te moni, o te hokohoko, o te aha, o te aha-Easy Lessons on money matters. Retrieved from http://nzetc.victoria. ac.nz/tm/scholarly/tei-WhaEasy-t1-front-d2 . html 